\title{
HUBUNGAN ANTARA PEMANFAATAN INTERNET SEBAGAI SUMBER BELAJAR DENGAN PRESTASI BELAJAR MAHASISWA SEMESTER III PRODI DIII KEBIDANAN SUTOMO SURABAYA
}

\author{
Oleh \\ Yuni Artati, Tumirah dan Suparmo \\ Prodi DIV Kebidanan Sutomo Surabaya
}

\begin{abstract}
Abstrak
Seiring dengan perubahan paradigma pembelajaran, maka keberhasilan kegiatan belajar mengajar di perguruan tinggi tidak hanya ditentukan oleh faktor pengajar/dosen, melainkan sangat dipengaruhi oleh keaktifan mahasiswa. Belajar sebagai bagian dari aktifitas mahasiswa merupakan perubahan yang relative permanen dalam perilaku atau potensi perilaku sebagai hasil dari pengalaman atau latihan yang diperkuat.

Internet sebagai salah satu sumber belajar dari adanya perkembangan teknologi informasi menjadi sangat berperan untuk meningkatkan prestasi belajar mahasiswa. Secara umum masih banyak mahasiswa yang belum menggunakan internet sebagai sumber belajar. Walaupun ada masih terbatas pemanfaatannya hanya untuk komunikasi dan hiburan. Sedangkan faktor-faktor yang mempengaruhi prestasi belajar seorang mahasiswa baik internal maupun eksternal seperti: kecerdasan emosional, minat dan bakat, metode pembelajaran, sarana dan prasarana(Internet), motivasai, cara belajar, dan kecerdasan intelektual. Untuk itu perlu dilakukan penelitian apakah ada hubungannya pemanfaatan internet terhadap prestasi mahasiswa.

Penelitian ini menggunakan pendekatan analitik, karena bertujuan untuk menganalisis, menjelaskan suatu hubungan, menguji berdasarkan teori yang ada dipakai untuk tujuan eksplorasi. Penelitian ini bertujuan melakukan pengukuran variabel independent dan dependent yang sesuai dari obyek yang diteliti. Analisis Statistik yang digunakan adalah uji Korelasi Pearson Product moment dengan taraf signifikansi 0,05 .

Hasil analisis korelasi terlihat bahwa nilai korelasi antara pemanfaatan internet sebagai sumber belajar dan nilai indeks prestasi mahasiswa semester III Prodi DIII Kebidanan Sutomo Surabaya sebesar 0,026, yang memiliki hubungan korelasi sangat lemah. Hal ini berarti terdapat hubungan yang sangat lemah antara pemanfaatan sumber belajar internet dengan nilai indeks prestasi mahaisiswa sehingga pemanfaatan internet sebagai sumber belajar tidak memberikan pengaruh sangat nyata (signifikan) terhadap indeks prestasi mahasiswa semester III Prodi DIII Kebidanan Sutomo Surabaya.
\end{abstract}

Kata Kunci : Sumber belajar Internet, Korelasi Pearson Product Moment, Indeks Prestasi

\section{PENDAHULUAN}

\section{Latar Belakang}

Proses pembelajaran harus berpusat pada peserta belajar, pengajar bukan sebagai satusatunya sumber belajar atau sumber informasi, melainkan berperan sebagai fasilitator, dinamisator, motivator dalam pembelajaran. Selaian sumber belajar berupa perpustakaan yang tersedia di kampus, sekarang ini berkembang teknologi internet yang memberikan kemudahan dan keleluasaan dalam menggali ilmu pengetahuan.Internet adalah jaringan informasi global sehungga manusia di seluruh dunia bisa saling berhubungan satu sama lain sehingga para siswa dapat mengkses secara online dari berbagai perpustakaan, museum, data base dan mendapatkan sumber primer tentang berbagai peristiwa sejarah, biografi, rekaman, laporan, data statistik atau kutipan yang berkaitan(Gordin et ai.1995) 
Seiring dengan perubahan paradigma pembelajaran, maka keberhasilan kegiatan belajar mengajar di perguruan tinggi tidak hanya ditentukan oleh faktor pengajar/dosen, melainkan sangat dipengaruhi oleh keaktifan mahasiswa. Belajar sebagai bagian dari aktifitas mahasiswa merupakan perubahan yang relative permanen dalam perilaku atau potensi perilaku sebagai hasil dari pengalaman atau latihan yang diperkuat.

Keaktifan mahasiswa dalam belajar dewasa ini perlu mendapat perhatian, umumnya mahasiswa kurang memilki kemauan yang keras untuk meraih keberhasilan belajar terutama dalam hal pemanfaatan sumber belajar. Minimnya pemanfaatan sumber belajar merupakan salah satu factor penyebab rendahnya hasil belajar sehingga menyebabkan menurunnya mutu pendidikan. Slameto (2003 : 76) mengemukakan bahwa factor cara belajar yang buruk merupakan penyebab masih cukup banyaknya siswa yang sebenarnya pandai tetapi hanya meraih prestasi yang tidak lebih baik dari siswa yang sebenarnya kurang pandai tetapi mampu meraih prestasi yang tinggi karena mempunyai cara belajar yang baik. Termasuk cara belajar yang baik adalah kemampuan mahasiswa secara aktif memanfaatkan sumber belajar secara efektif dan efisien sehingga berpengaruh pada peningkatan prestasi belajar mahasiswa.

Indeks prestasi mahasiswa dari setiap semester mengalami penurunan yang signifikan terutama pada predikat sangat memuaskan. Dari $100 \%$ pada semester 1 kemudian turun menjadi $45,2 \%$ pada semester III terjadi penurunan $54,8 \%$ pada predikat memuaskan mengalami peningkatan dari $0 \%$ pada semester 1 menjadi $54,7 \%$ pada semester III atau mengalami peningkatan 45,3\%, kearah yang negative sedangkan pada predikat dengan pujian masih seimbang.

Sedangkan hasil rekapan pengunjung laboratorium internet di prodi DIII kebidanan sutomo tahun akademik 2008/2009, pada semester I sebanyak 19,87 \%, semerter II 24,76 \%, semester III $8,2 \%$. Dari hasil tersebut dapat diklarifikasi mahasiswa yang paling aktif memanfaatkan internet di lingkungan kampus prodi DIII sutomo adalah semester II dan kunjunganya sedikit adalah mahasiswa semester III. Selama ini upaya yang telah dilakukan pihak pendidikan adalah dengan memberikan pemahaman, motivasi, bimbingan, dan arahan kepada mahasiswa untuk lebih memanfaakan sarana internet yang telah disediakan. Oleh karena itu penulis tertarik untuk melakukan penelitian tentang "hubungan antara pemanfaatan internet sebagai sumber belajar dengan prestasi belajar mahasiswa semester III di prodi kebidanan Sutomo Surabaya "

\section{Identifikasi penyebab masalah}

Internet sebagai salah satu sumber belajar dari adanya perkembangan teknologi informasi menjadi sangat berperan untuk meningkatkan prestasi belajar mahasiswa. Secara umum masih banyak mahasiswa yang belum menggunakan internet sebagai sumber belajar. Walaupun ada masih terbatas pemanfaatannya hanya untuk komunikasi dan hiburan. Sedangkan faktor-faktor yang mempengaruhi prestasi belajar seorang mahasiswa baik internal maupun eksternal seperti: kecerdasan emosional, minat dan bakat, metode pembelajaran, sarana dan prasarana(Internet), motivasai, cara belajar, dan kecerdasan intelektual. Untuk itu perlu dilakukan penelitian apakah ada hubungannya pemanfaatan internet terhadap prestasi mahasiswa.

\section{Batasan Masalah}

Penelitian ini dilakukan pada mahasiswa semester III di prodi DIII kebidanan sutomo surabaya yang memanfaatkan internet di lingkungan kampus dalam satu semester.

\section{LANDASAN TEORI}

\section{Internet Sebagai Sumber Belajar}

Internet singkatan dari International Network, adalah jaringan informasi global sehingga manusia di seluruh dunia bisa saling berhubungan satu sama lain. secara harfiah mengandung 
pengertian sebagai jaringan komputer yang menghubungkan beberapa rangkaian . Jaringan internet juga didefinisikan sebagai jaringan komputer yang mampu menghubungkan komputer di seluruh dunia sehingga berbagai jenis dan bentuk informasi dapat dikomunikasikan antar belahan dunia secara instan dan global (Marsell,2005). Selain kedua pengertian di atas, internet juga disebut sebagai sekumpulan jaringan komputer yang menghubungkan situs akademik, pemerintahan, komersial, organisasi, maupun perorangan. Internet menyediakan akses untuk layanan telekomunikasi dari sumber daya informasi untuk jutaan pemakainya yang tersebar di seluruh dunia. Layanan internet meliputi komunikasi langsung (e-mail, chat), diskusi (usenet news, milis, bulletin board), sumber daya informasi yang terdistribusi (World Wide Web, Ghoper), remote login dan lalu lintas file (Telnet, FTP), serta berbagai layanan lainnya (Andhika,2005).

Pemanfatan internet sebagai sumber pembelajaran mengkondisikan siswa untuk belajar secara mandiri. Cobine(1997) menyatakan bahwa Through Independent Study, student become doers, as wel ass thinker.Para siswa dapat mengakses secara online dari berbagai perpustakaan, museum, data base, dan mendapatkan sumber primer tentang berbagai peristiwa sejarah, biografi, rekaman, laporan, data statistik, atau kutipan yang berkaitan(Gordin et.al1995)

\section{Sumber Belajar}

Shahahuddin(1990: 29) mendifinisikan bahwa"belajar adalah suatu proses perubahan tingkah laku melalui pendidikan atau lebih khusus melalui prosedur latihan. Perubahan itu sendiri berangsur-angsur dimulai dari suatu yang tidak dikenal untuk kemudian dikuasai dan dimilikinya dan digunakannya sampai pada suatu saat dievaluasi oleh yang menjalani proses belajar itu. Menurut Association for Educational Communications and Technology sumber pembelajaran adalah segala sesuatu atau daya yang dapat dimanfaatkan oleh guru, baik secara terpisah maupun dalam bentuk gabungan, untuk kepentingan belajar mengajar dengan tujuan meningkatkan efektivitas dan efisiensi tujuan pembelajaran.

\section{Konsep dasar prestasi belajar}

Istilah hasil belajar dari bahsa Belanda " prestatie,"dalam bahasa Indonesia menjadi prestasi yang beraarti hasil usaha. Dalam literature, prestasi selalu dihubungkan dengan aktivitas tertentu, seperti dikemukakan Robert M. Gagne ( 1988) dalam Abdullah (2009) bahwa dalam setiap proses akan selalu terdapat hasil nyata yang dapat diukur dan dinyatakan sebagai hasil belajar sesorang .

Prestasi adalah hasil yang dicapai. Prestasi dapat diartikan hasil yang diperoleh karena adanya aktifitas belajar yang telah dilakukan (Ridwan, 2008) Menurut Poerwanto (1986) dalam Ridwan (2009) memberikan pengertian prestasi belajar yaitu " hasil yang dicapai oleh seseorang dalam usaha belajar sebagaimana yang dinyatakan dalam raport"

Winkel (1996) dalam Ridwan (2009) mengemukakan bahwa prestasi belajar merupakan bukti keberhasilan yang telah dicapaia oleh seseorang. Maka prestasi belajar merupakan hasil maksimum yang dicapai oleh seseorang setelah melaksanakan usaha - usahah belajar.

Muhibbin Syah (2003) menjelaskan bahwa " Prestasi belajar merupakan taraf keberhasilan murid atau santri dalam mempelajari materi pelajaran di sekolah atau pondok pesantren dinyatakan dalam bentuk skor yang diperoleh dari hasil tes mengenai sejumlah materi pelajaran tertentu.

Tes prestasi berupa test yang disusun secara terencana untuk mengungkapkan performans maksimal subyek dalam menguasai bahan atau materi yang telah diajarkan. Dalam pendidikan formal di kelas, tes prestasi belajar dapat berbentuk ulangan harian, tes formatif, tes sumatif, ebtanas, dan ujian masuk perguruan tinggi ( Azwar Syaifuddun, 2007)

Jadi prestasi belajar adalah hasil pengukuran dari penilaian usaha belajar yang dinyatakan dalam bentuk symbol, huruf maupun kalimat yang menceritakan hasil yang sudah dicapai oleh 
setiap anak pada periode tertentu.Prestasi belajar siswa dapat diketahui setelah diadakan evaluasi. Hasil dari evaluasi dapat memperlihatkan tentang tinggi atau randahnya prestasi belajar siswa.

\section{Indikator prestasi belajar}

Benyamin, S, Bloom dalam Syah M, 2009 membagi kawasan belajar yang mereka sebut sebagai tujuan pendidikan menjadi tiga bagian yaitu kognitif, kawasan afektif dan psikomotor. Sebagai seorang guru atau dosen haruslah mengetahui dasar - dasar penyusunan tes prestasi belajar yang baik agar dapat memperoleh hasil ukur yang akurat (Valid) dan dapat dipercaya (Reliabel). Pada prinsipnya pengungkapan hasil belajar ideal meliputi segenap ranah psikologis yang berubah sebagai akibat pengalaman dan proses belajar siswa. Kunci pokok untuk memperoleh ukuran dan data hasil harus mengetahui garis besar indicator ( petunjuk adanya prestasi tertentu) dikaitkan dengan jenis prestasi yang hendaka diungkapkan atau diukur. Seperti kawasan kognitif dengan penekanan pada bentuk tes tertulis.

\section{Desain Penelitian}

\section{METODE PENELITIAN}

Penelitian ini menggunakan pendekatan analitik, karena bertujuan untuk menganalisis, menjelaskan suatu hubungan, menguji berdasarkan teori yang ada (Nursalam, 2001) dipakai untuk tujuan eksplorasi. Penelitian ini bertujuan melakukan pengukuran variabel independent dan dependent yang sesuai dari obyek yang diteliti.

\section{Kerangka Operasional Penelitian}

Kerangka operasional (kerangka kerja) adalah pemahaman langkah-langkah dalam aktivitas ilmiah mulai dari penerapan populasi sampel dan seterusnya yaitu kegiatan sejak awal penelitian.

\section{Populasi Penelitian}

Populasi dan wilayah generalisasi penelitian ini adalah mahasiswa DIII Kebidanan Semester III tahun akademik 2009/2010 Sutomo Surabaya. Populasi dalam penelitian ini adalah 82 orang.

\section{Sampel}

Pada penelitian ini sampel diambil sesuai dengan kebutuhan penelitian yaitu sebagian Mahasiswa semester III Kebidanan tahun akademik 2009/2010 Prodi Kebidanan Sutomo Surabaya.

\section{Besar Sampel}

Untuk menentukan besar sampel digunakan rumus menurut Arikunto (2002).

$$
\begin{aligned}
& \mathrm{n}=\frac{\mathrm{N}}{\mathrm{K}} \\
& \mathrm{K} \quad: \text { :tera } \\
& \mathrm{N} \quad: \text { Besar sampel populasi : } 82 \\
& \mathrm{~d} \quad: \text { Tingkat signifikasi }(\mathrm{p}): 0,05 \\
& \mathrm{n} \quad= \\
& \mathrm{n} \quad=\frac{\mathrm{N}}{1+\mathrm{N}(\mathrm{d})^{2}} \\
& \quad \frac{82}{1+82(0,05)^{2}}
\end{aligned}
$$




$$
\begin{aligned}
& \mathrm{n}=\frac{82}{\mathrm{n}}=\frac{82}{1+82(0,025)} \\
& \mathrm{n}=\frac{1+0,205}{\frac{82}{1,205}}
\end{aligned}
$$

Jadi besar sampel yang digunakan dalam penelitian ini adalah 68 responden.

\section{Teknik Pengambilan Sampel (Sampling)}

Pada penelitian ini menggunakan teknik Simple Random Sampling, yaitu mahasiswa semester III di Prodi DIII Kebidanan Sutomo Surabaya. Seluruh populasi dianggap homogen dan setiap obyek populasi mempunyai kemungkinan yang sama untuk diambil sebagai sampel.

\section{Variabel Penelitian}

Variabel penelitian adalah suatu ukuran atau ciri yang dimiliki oleh anggota suatu kelompok (orang, benda, situasi) yang berbeda dengan yang dimiliki oleh kelompok lain.

a. Variabel Independent

Variable independent dalam penelitian ini adalah pemanfaatan Internet, karena pemanfaatan internet sebagai sumber belajar diduga mempengaruhi prestasi belajar.

b. Variable Dependent

Variabel dependent pada penelitian ini adalah prestasi belajar mahasiswa semester III Prodi D III Kebidanan Sutomo Surabaya.

\section{Analisis data}

Data yang terkumpul akan dikoreksi dan dikumpulkan sesuai variable yang akan diukur, selanjutnya untuk mengetahui hubungan antara 2 variabel dengan skala ordinal maka analisis dan pengolahan data menggunakan uji korelasi Pearson Product Moment dengan tingkat signifikan $\alpha=$ 0,05. Apabila hasil uji statistic didapatkan $r_{x y}$ hitung $\geq r_{x y}$ table, maka hipotesis nol ditolak yang berarti ada hubungan antara penggunaan internet sebagai sumber belajar dengan prestasi belajar. Sebaliknya apabila hasil uji statistic $r_{x y}$ hitung $\leq r_{x y}$ table, maka hipotesis nol diterima yang berarti tidak ada hubungan antara penggunaan internet sebagai sumber belajar dengan prestasi belajar mahasiswa.

Rumus dari perhitungan secara statistic koefisien korelasi Pearson Product Moment (PPM) :

$$
r_{x y}=\frac{\sum x y}{\left(\sum x^{2}\right)\left(\sum y^{2}\right)}
$$

keterangan : rxy $=$ Koefisien Korelasi Variabel $\mathrm{x}$ dan variabel $\mathrm{y}$.

$\sum \mathrm{xy}=$ Hasil kali dari $\mathrm{x}$ kali $\mathrm{y}$.

$\sum \mathrm{x}^{2}=$ Jumlah nilai variable $\mathrm{x}$ yang di kuadrakan dalam nilai kunjungan internet mahasiswa dikurangi nilai rata-rata kunjungan. 


\section{$\sum y^{2}=$ Jumlah nilai variable y yang di kuadratkan dalam nilai Indeks prestasi mahasiswa semester III dikurangi nilai rata-rata IP.}

\section{HASIL PENELITIAN}

\section{Analisis Korelasi}

Untuk melihat ada tidaknya pengaruh antara variable pemanfaatan internet sebagai sumber belajar dengan nilai indeks prestasi mahasiswa dilakukan uji statistic dalam bentuk analisis Korelasi Perason Product Momen. Hasil analisis terlihat pada table berikut:

$$
r_{x y}=\frac{\sum x y}{\sqrt{\left(\sum x^{2}\right)\left(\sum y^{2}\right)}}
$$

keterangan : rxy $=$ Koefisien Korelasi Variabel $\mathrm{x}$ dan ariable $\mathrm{y}$.

$$
\begin{aligned}
& \sum x y=29,7223 \\
& \sum x^{2}=253,289 \\
& \sum y^{2}=4,4495
\end{aligned}
$$

Jadi $r_{x y}=\frac{29,7223}{\sqrt{(253,289)(4,4495)}}=\frac{29,7223}{1.127,01}=0,026$

Hasil analisis korelasi terlihat bahwa nilai korelasi antara pemanfaatan internet sebagai sumber belajar dan nilai indeks prestasi mahasiswa semester III Prodi DIII Kebidanan Sutomo Surabaya sebesar 0,026, yang memiliki hubungan korelasi sangat lemah. Hal ini berarti terdapat hubungan yang sangat lemah antara pemanfaatan sumber belajar internet dengan nilai indeks prestasi mahaisiswa sehingga pemanfaatan internet sebagai sumber belajar tidak memberikan pengaruh sangat nyata (signifikan) terhadap indeks prestasi mahasiswa semester III Prodi DIII Kebidanan Sutomo Surabaya.

Berdasarkan arah korelasi diperoleh nilai positif, yang berarti walaupun ada pengaruh yang sanagt lemah bahwa antara pemanfaatan internet sebagai sumber belajar dan nilai indeks prestasi memiliki hubungan yang positif dimana semakin tinggi nilai pemanfaatan internet sebagai sumber belajar akan menaikkan nilai indeks prestasi mahasiswa, begitu pula sebaliknya.

Seberapa besar variable penentu antara pemanfaatan internet sebagai sumber belajar dan indeks prestasi mahasiswa dengan melihat nilai koefisien determinan (KP), yaitu :

$$
\begin{aligned}
\mathrm{KP} & =\mathrm{r}^{2} \times 100 \% \\
& =0,026^{2} \times 100 \% \\
& =0,0676 \\
& =6,76 \%
\end{aligned}
$$


Dari hasil perhitungan nilai koefisien determinat diperoleh sebesar 6,76 \%, yang berarti pengaruh yang terjadi antara pemanfaatan internet dengan indeks prestasi mahasiswa ditentukan sebesar 6,76 $\%$. Selebihnya ditentukan oleh factor lain.

\section{PEMBAHASAN}

\section{Deskripsi Variabel}

\section{Pemanfaatan Internet sebagai Sumber Belajar}

Indikator untuk mengetahui besarnya pemanfaatan internet sebagai sumber belajar adalah dengan menggunakan jumlah kunjungan mahasiswa per harinya selama satu semester, khususnya semester III dimulai dari bulan september tahun 2009 sampai bulan februari tahun 2010. Selama satu semester tersebut didapatkan jumlah kunjungan sebanyak 213 mahasiswa dari 68 mahasiswa yang diamati sebagai responden.

Rata-rata kunjungan sebesar 3,13, yang berarti selama satu semester tersebut setiap mahasiswa hanya melakukan kunjungan sebanyak 3 kali. Mahasiswa yang paling banyak melakukan kunjungan adalah sebanyak 10 kali dan yang paling sedikit melakukan kunjungan sebanyak 1 kali. Hal ini secara umum mahasiswa masih terlalu sedkit yang melakukan kunjungan di laboratorium internet yang berarti mahasiswa belum banyak memanfaatkan internet sebagai sumber belajar.

\section{Indeks Prestasi Mahasiswa}

Indikator dari prestasi belajar mahaasiswa yang dilihat adalah indeks prestasi mahasiswa pada semester III. Dari 68 mahasiswa yang dijadikan responden diperoleh nilai Indeks prestasi rata-rata sebesar 2,85. Indeks prestasi tertinggi sebesar 3,35 dan terendah sebesar 2,09. Secara umum prestasi belajar mahasiswa semester III adalah baik. Nilai ini tergolongan belum memuaskan bila dilihat nilai per mahasiswa $21 / 68 \times 100 \%=30,9 \%$ memiliki IP $\geq 3,00$ sebesar $30,9 \%$ lebih sedikit dibandingkan mahasiswa yang memiliki IP $\leq 3,00$ sebesar $69,1 \%$.

\section{Hubungan antar Variabel}

Mahasiswa yang memanfaatkan internet sebagai sumber belajar masih rendah dimana ratarata mahasiswa yang melakukan kunjungan ke laboratorium internet selama satu semester sebesar 3 kali per mahasiswa. Selain itu prestasi belajar mahasiswa tergolong baik, namun masih banyak mahasiswa yang memiliki IP di bawah 3,00 yaitu sebesar 69,1\%.

Hasil analisis statistik dengan uji korelasi Pearson Product Moment diperoleh sebesar 0,026, berarti memilki pengaruh yang sangat lemah antara pemanfaatan internet terhadap prestasi belajar mahasiswa. Hal ini berarti tidak ada pengaruhnya antara pemanfaatan internet dengan tingkat prestasi belajar mahasiswa. Prestasi belajar tidak hanya tergantung pada pemanfaatan sumber belajar internet, namun juga tergantung pada faktor-faktor lain. Hal ini sejalan dengan pendapat Nelda (2005) yang mengemukakan bahwa banyak faktor yang mempengaruhi prestasi belajar seorang mahasiswa baik internal maupun eksternal seperti: kecerdasan emosional, minat dan bakat, metode pembelajaran, sarana dan prasarana, motivasi, cara belajar, dan Kecerdasan intelektual. 


\section{KESIMPULAN DAN SARAN}

\section{Kesimpulan}

Berdasarkan hasil penelitian yang telah dilakukan analisis tentang pemanfaatan internet sebagai sumber belajar dan tingkat prestasi mahasiswa semester III Prodi DIII Kebidanan Sutomo Surabaya dapat ditarik kesimpulan sebagai berikut:

a. Mahasiswa yang memanfaatkan internet sebagai sumber belajar masih rendah, yaitu dalam satu semester rata-rata per mahasiswa yang melakukan kunjungan ke laboratorium internet sebanyak 3 kali.

b. Tingkat prestasi mahasiswa semester III Prodi DIII Kebidanan baik dengan rata-rata IP sebesar 2, 85. Namun mahasiswa yang memiliki IP di bawah 3,00 masih banyak yaitu sebesar $69,1 \%$.

c. Tidak terdapat pengaruh yang signifikan antara pemanfaatan internet sebagai sumber belajar terhadap prestasi belajar mahasiswa semester III Prodi Kebidanan Sutomo Surabaya dengan nilai korelasi sebesar 0,026 yang berarti memiliki korelasi sangat lemah atau dianggap tidak memiliki korelasi.

\section{Saran-saran}

a. Perlu dilakukan penelitian lebih lanjut ada tidaknya pengaruh faktor-faktor lainnya yang mempengaruhi prestasi belajar mahasiswa.

b. Perlu dilakukan penelitian lebih lanjut ada tidaknya hubungan antara faktor internal dan eksternal terhadap prestasi belajar mahasiswa.

\section{Daftar Pustaka}

Andhika. (2005). Apa itu Internet? (www. andhika.com), diambil 25 Mei 2010.

Ainurrohman, 2009. Belajar dan Pembelajaran. CV. Alfa Beta Bandung.

Alimul A, 2007 Metode Penelitian Kebidanan Teknik Analisis Data. Penerbit Salemba Medika Jakarta.

Arif A Mangkoesapoetro. (2004). Pemanfaatan Media Massa Sebagai Sumber Pembelajaran IPS di Tingkat Persekolahan. (http://artikel.us/mangkoes6-04-2.html). diambil 27 Mei 2010.

Arikunto, Suharsimi (2002). Dasar-dasar Evaluasi Pendidikan. Bumi aksara, Jakarta.

Cobin, GR (1997) Studying With The Computer. Eric Digest. (Online) Tersedia http://www.ericfacility.net/ericdigests/ed4550061html (28 April 2010)

Gordin, DL. Et.al (1995) "Using The Worl Wid Web To Build Learning Communities" Northwestern University Magazine. April, 1 - 17

Harahap, Nasrun, 1999. Prestasi Belajar Dan Kompetensi Guru. Balai Pustaka Jakarta.

Hestryana, 2006 Pengaruh Faktor-Faktor Keberhasilan Studi Terhadap Prestasi Akademik Mahasiswa Jurusan Managemen Alih Jalur. Fakultas Ekonomi Universitas Airlangga Surabaya. Skripsi Fakultas Ekonomi Universitas Airlangga Surabaya. 
Marsell Ruben Payong. (2005). Good Bye Teacher. (www.kompas.com). diambil 24 Mei 2010.

Martin, A. dan Bhaskara 2002. Kamus Bahasa Indonesia Millenium. Penerbit Karina, Surabaya.

Nelda Azhar. 2005. Kontribusi Kecerdasan Emosional Motivasi Berprestasi Dan Cara Belajar Terhadap Prestasi Belajar Fisika Terapan Mahasiswa Teknik Elektronika Fakultas Teknik Universitas Negeri Padang. Tesis Program Pasca Sarjana UNP Malang.

Oetomo, B. S. D, Wibowo, E., Hartono, S., dan Prakoso, S., (2007) Pengantar Teknologi Informasi Internet : Konsep dan Aplikasi, Penerbit Andi, Yogyakarta.

Philip Rechdalle.(2005). Internet dan Pendidikan. (www.pendidikan.net). Diambil 24 Mei 2010.

Prabowo, 2006. Pengaruh Kemampuan Dan Motivasi Berprestasi Tehadap Prestasi Akademik Mahasiswa Jurusan Managemen Fakultas Eknomi Unair Surabaya. Skripsi Fakultas Ekonomi Universitas Airlangga Surabaya.

Purbo. U. W. (2002) "Perkembangan Teknologi Informasi dari Internet di Indonesia, Kompas (28 Juni 2000).

Purwo Darminto, WJS. 1999. Kamus Bahasa Indonesia, Departemen Pendidikan dan Kebudayaan Balai Pustaka, Jakarta.

Rennie, F. Dan Mason, R. (2004). ELEARNING panduan lengkap memahami dunia digital dan internet. Penerbit Pustaka Baca, Yogyakarta.

Shalahuddin, Mahfud (1990). Pengantar Psikologi Pendidikan, EGC, Jakarta.

Slameto, (2003). Belajar dan Faktor-faktor yang Mepengaruhi, Rineka Cipta, Jakarta.

Soeharto, K., Soeprajitno, Sudjimat dan Sulton (2003). Teknologi Pembelajaran. Penerbit SIC Surabaya.

W.S. Winkel. 1991, Psikologi Pengajaran EGC Surabaya. 